\title{
Maternal fertility, reproductive loss, and defective human embryos
}

\author{
KOHEI SHIOTA \\ From the Congenital Anomaly Research Centre, Faculty of Medicine, Kyoto University, Kyoto 606, Japan
}

ABSTRACT It is possible that many abnormal conceptuses are lost at an early stage without the mother's knowledge. To investigate this further the reproductive history of the mothers of defective embryos (neural tube defects, holoprosencephaly, cleft lip, polydactyly, and early embryonic resorption) was compared with that of the mothers of normal embryos. The frequency of prior miscarriages was higher in the case mothers than in normal controls matched for maternal age and gravidity, the difference being significant for all the anomalies except for polydactyly. The case mothers had fewer prior recognised pregnancies than control mothers matched for maternal age. There were more primigravid mothers in abnormal groups, and the difference from controls was significant for neural tube defects. It was assumed that the gravidity of the case mothers may be underestimated, possibly due to increased early abortions which are not recognised clinically. Thus, it seems that both recognised and unrecognised abortions occur more often in the mothers of defective embryos. Since many spontaneous abortuses are morphologically and/or cytogenetically abnormal, some women appear to conceive abnormal embryos repeatedly. Most of these embryos, however, may be screened out prenatally and escape clinical detection. Information on prior reproductive history of the woman should be examined carefully in genetic counselling.

The prevalence of malformations is much higher in prenatal human populations than in newborn infants. Based on the study of a large number of therapeutic abortuses in Japan, Nishimura ${ }^{1}$ showed that the prevalences of specific malformations were at least several times higher than those in newborn infants. Such a difference between the two populations has been observed not only for lethal malformations such as neural tube defects but also for less serious anomalies which may not in themselves be lethal, such as oral clefts and limb malformations. Thus many embryos malformed at organogenesis appear to be eliminated prenatally and may not be recognised at birth. This is supported by the fact that nearly half of spontaneous abortuses are morphologically and/or cytogenetically abnormal. ${ }^{2-4}$ Creasy and Alberman ${ }^{5}$ studied a series of 2658 spontaneous abortions and estimated the prevalence of anencephaly and spina bifida to be $5 \cdot 3$ per 1000 at 8 weeks of gestation, $4 \cdot 1$ at 12 weeks, 3.0 at 20 weeks, and 2.8 at 27 weeks. Their findings suggest that $54 \%$ of these abnormal fetuses abort spontaneously between 8 and 27 weeks of gestation. Hook ${ }^{4}$ estimated that the proportion of chromosomally affected conceptuses is $5 \%$ among all recognisable pregnancies and drops to $4.2 \%$ at 8 weeks, $2 \cdot 4 \%$ at 12 weeks, $1 \cdot 1 \%$ at 16 weeks, $0.8 \%$ at 20 weeks and $0.6 \%$ in livebirths. These findings clearly show the selective intrauterine death of abnormal embryos and fetuses.

It has recently been reported that a substantially large proportion of human conceptions confirmed immunologically soon after implantation are lost at such an early stage of gestation that the mothers are unaware that conception has occurred. ${ }^{67}$ Since the prenatal elimination rate of defective conceptuses is high and since a large proportion of early intrauterine deaths may not be clinically recognised, it seems that many abnormal conceptuses in early pregnancies are eliminated without the knowledge of the mother. This is important in genetic counselling because the occurrence of abnormal conceptions may often escape detection and therefore the familial clustering of malformations can be significantly underestimated.

Using a large collection of human embryos in Japan, we analysed the reproductive histories of the women who conceived a defective embryo. The derived information would be of some significance in estimating the fate of early human conceptuses, especially those of predisposed women.

\section{Methods}

The human embryos used in the present study were from the collection of human conceptuses in the 
Congenital Anomaly Research Centre of Kyoto University. The embryo collection is composed of about 40000 human conceptuses, most of which were procured after induced abortion. The details of the embryo collection were described previously. ${ }^{18}$ Reproductive history of each mother was taken by attending physicians using a standard interview form before or shortly after the termination of pregnancy. Since the physicians did not examine the embryo, neither the physicians nor the mothers were aware of the abnormalities in the embryo and therefore the reporting bias and maternal memory bias should be minimal.

From the collection, 282 malformed embryos and 424 empty chorionic sacs were selected for the present study. The malformed embryos had a neural tube defect, holoprosencephaly, cleft lip with or without cleft palate, or polydactyly. Among them, 231 cases had an isolated anomaly and the remaining 51 cases had two or three external anomalies. Empty chorionic sacs are intact sacs without proper embryonic tissue and are considered to be products of very early embryonic resorption. All the study cases were the products of induced abortion and the anomalies were found on routine examination in the laboratory. Cases referred after antenatal diagnosis or after physicians' knowledge of anomalies were not included in the present study.

The reproductive histories of the mothers of defective embryos were compared with those of normal embryos procured after induced abortion. For comparison of prior abortions, one normal embryo for each abnormal case was drawn from the collection, matched for maternal age, maternal gravidity (the number of prior pregnancies except induced abortions), gestational age at termination of pregnancy ( \pm 2 days), and the year of procurement. For analysis of the number of prior pregnancies, control cases were matched with each index case for maternal age, gestational age ( \pm 2 days), and the year of procurement. When two or more cases were eligible as a control, the case was chosen whose termination immediately followed that of the study case.

Statistical analyses were performed using $\chi^{2}$ test for comparing percentages and Student's $t$ test for comparing means.

\section{Results}

Table 1 shows the data on maternal age, gravidity, and previous miscarriages in the mothers of defective conceptuses. The average maternal age ranged from $29 \cdot 2$ for neural tube defects to 30.6 for empty chorionic sacs, but these figures did not differ significantly from each other and from the average maternal age $(30 \cdot 2)$ for the total embryo population under study. 9

The frequency of previous reproductive loss was compared between the mothers of defective embryos and those of normal embryos matched for maternal age and gravidity. The frequencies of prior spontaneous abortions clinically recognised are shown in table 2. The proportions of the women who had experienced any recognised miscarriages were $35.8 \%$ $(19 / 53)$ for neural tube defects, $30.0 \%(21 / 70)$ for holoprosencephaly, $31 \cdot 3 \%(21 / 67)$ for cleft lip, $24 \cdot 3 \%$ $(17 / 70)$ for polydactyly, and $34.5 \%(122 / 355)$ fore empty chorionic sacs, and the difference from norma controls was statistically significant for emptye chorionic sacs $\left(\chi^{2}=31.7, \mathrm{p}<0.01\right)$ and total defective embryos $\left(\chi^{2}=35.5, \mathrm{p}<0.01\right)$. The average number of previous abortions was 0.51 in the mothers of defective embryos and 0.24 in the normal controls $(\mathrm{p}<0.01)$ The average number of abortions was significantly? larger than that of controls in the cleft lip and empty chorionic sac groups.

In table 3, the proportions of prior pregnancies which ended in spontaneous abortion are shown. The rate of recognised abortions was fairly constant $(12 \cdot 1-$ $14.3 \%$ ) in the mothers of normal embryos. In the groups of defective embryos, however, it varied from $17.3 \%$ in the mothers of polydactyly embryos to $33.8 \%$ in those of cleft lip embryos. The difference

Table 1 Maternal age and reproductive history of the mothers of defective embryos

\begin{tabular}{|c|c|c|c|c|c|c|c|c|}
\hline \multirow{3}{*}{$\frac{\text { Anomaly }}{\text { Neural tube defects }}$} & \multirow{3}{*}{$\begin{array}{l}\begin{array}{l}\text { Number of } \\
\text { cases }\end{array} \\
72\end{array}$} & \multirow{3}{*}{$\begin{array}{l}\begin{array}{l}\text { Mean } \\
\text { maternal } \\
\text { age (years) }\end{array} \\
29 \cdot 2\end{array}$} & \multicolumn{2}{|c|}{$\begin{array}{l}\text { Number of prior } \\
\text { pregnancies }\end{array}$} & \multicolumn{2}{|c|}{$\begin{array}{l}\text { Number of prior } \\
\text { miscarriages }\end{array}$} & \multirow{2}{*}{\multicolumn{2}{|c|}{$\begin{array}{l}\text { Percentage of } \\
\text { miscarriages in } \\
\text { prior pregnancies }\end{array}$}} \\
\hline & & & \multirow{2}{*}{$\frac{\text { mean }}{1.94}$} & \multirow{2}{*}{$\frac{S E}{0.24}$} & \multirow{2}{*}{$\begin{array}{l}\text { mean } \\
0.47\end{array}$} & \multirow{2}{*}{$\frac{S E}{0.10}$} & & \\
\hline & & & & & & & $24 \cdot 8$ & $(25 / 101)$ \\
\hline Holoprosencephaly & 88 & $30 \cdot 2$ & 2.67 & 0.25 & 0.46 & $0 \cdot 10$ & 22.9 & $(32 / 140)$ \\
\hline Cleft lip & 84 & 29.9 & 2.44 & 0.23 & 0.65 & 0.15 & 33.8 & $(45 / 133)$ \\
\hline Empty chorionic sac & 424 & $30 \cdot 6$ & $2 \cdot 89$ & $0 \cdot 12$ & 0.54 & 0.05 & 25.9 & $(192 / 741)$ \\
\hline Totalt & 706 & $30 \cdot 2$ & 2.69 & 0.09 & 0.51 & 0.03 & $26 \cdot 0$ & $(299 / 1151)$ \\
\hline
\end{tabular}

* Excluding induced abortions.

t Cases with two or more anomalies under study were counted only once. 
Table 2 Previous recognised abortions in multigravid mothers of defective and normal embryos

\begin{tabular}{|c|c|c|c|c|c|c|c|c|c|c|}
\hline \multirow[b]{2}{*}{ Anomaly in index case } & \multirow[b]{2}{*}{ Group } & \multirow{2}{*}{$\begin{array}{l}\text { Number of } \\
\text { multigravid } \\
\text { mothers }\end{array}$} & \multicolumn{7}{|c|}{ Number of previous spontaneous abortions } & \multirow[b]{2}{*}{ Significance } \\
\hline & & & 0 & 1 & 2 & 3 & $4+$ & Mean & Variance & \\
\hline Neural tube defects & $\begin{array}{l}\text { Cases } \\
\text { Controls* }\end{array}$ & $\begin{array}{l}53 \\
53\end{array}$ & $\begin{array}{l}34 \\
40\end{array}$ & $\begin{array}{l}14 \\
13\end{array}$ & $\begin{array}{l}4 \\
0\end{array}$ & $\begin{array}{l}1 \\
0\end{array}$ & $\begin{array}{l}0 \\
0\end{array}$ & $\begin{array}{l}0.47 \\
0.25\end{array}$ & $\begin{array}{l}0.52 \\
0.19\end{array}$ & NS \\
\hline Holoprosencephaly & $\begin{array}{l}\text { Cases } \\
\text { Controls* }\end{array}$ & $\begin{array}{l}70 \\
70\end{array}$ & $\begin{array}{l}49 \\
57\end{array}$ & $\begin{array}{r}14 \\
9\end{array}$ & $\begin{array}{l}4 \\
2\end{array}$ & $\begin{array}{l}2 \\
2\end{array}$ & $\begin{array}{l}1 \\
0\end{array}$ & $\begin{array}{l}0.46 \\
0.27\end{array}$ & $\begin{array}{l}0.72 \\
0.43\end{array}$ & NS \\
\hline Cleft lip & $\begin{array}{l}\text { Cases } \\
\text { Controls* }\end{array}$ & $\begin{array}{l}67 \\
67\end{array}$ & $\begin{array}{l}46 \\
53\end{array}$ & $\begin{array}{l}11 \\
11\end{array}$ & $\begin{array}{l}2 \\
2\end{array}$ & $\begin{array}{l}3 \\
0\end{array}$ & $\begin{array}{l}5 \\
1\end{array}$ & $\begin{array}{l}0.67 \\
0.28\end{array}$ & $\begin{array}{l}1.59 \\
0.45\end{array}$ & $\mathrm{p}<0.05$ \\
\hline Polydactyly & $\begin{array}{l}\text { Cases } \\
\text { Controls* }\end{array}$ & $\begin{array}{l}70 \\
70\end{array}$ & $\begin{array}{l}53 \\
61\end{array}$ & $\begin{array}{r}13 \\
6\end{array}$ & $\begin{array}{l}3 \\
1\end{array}$ & $\begin{array}{l}1 \\
0\end{array}$ & $\begin{array}{l}0 \\
2\end{array}$ & $\begin{array}{l}0 \cdot 31 \\
0 \cdot 24\end{array}$ & $\begin{array}{l}0.39 \\
0.68\end{array}$ & NS \\
\hline Empty chorionic sac & $\begin{array}{l}\text { Cases } \\
\text { Controls* }\end{array}$ & $\begin{array}{l}355 \\
355\end{array}$ & $\begin{array}{l}233 \\
299\end{array}$ & $\begin{array}{l}71 \\
40\end{array}$ & $\begin{array}{l}37 \\
12\end{array}$ & $\begin{array}{r}10 \\
3\end{array}$ & $\begin{array}{l}4 \\
1\end{array}$ & $\begin{array}{l}0.54 \\
0.22\end{array}$ & $\begin{array}{l}0.79 \\
0.32\end{array}$ & $\mathrm{p}<0.01$ \\
\hline Totalt & $\begin{array}{l}\text { Cases } \\
\text { Controls* }\end{array}$ & $\begin{array}{l}583 \\
583\end{array}$ & $\begin{array}{l}393 \\
482\end{array}$ & $\begin{array}{r}118 \\
75\end{array}$ & $\begin{array}{l}47 \\
17\end{array}$ & $\begin{array}{r}15 \\
5\end{array}$ & $\begin{array}{r}10 \\
4\end{array}$ & $\begin{array}{l}0.51 \\
0.24\end{array}$ & $\begin{array}{l}0.80 \\
0.39\end{array}$ & $p<0.01$ \\
\hline
\end{tabular}

* Normal controls matched for gravidity (excluding induced abortions), maternal age, and embryonic age at termination of pregnancy. t Cases having two or more anomalies under study were counted only once.

NS $=$ Not significant.

Table 3 Proportion of prior pregnancies which ended in spontaneous abortion in mothers of defective and normal embryos

\begin{tabular}{|c|c|c|c|c|c|c|c|c|}
\hline \multirow[b]{3}{*}{ Anomaly in index case } & \multirow{3}{*}{$\begin{array}{l}\text { Numbers of } \\
\text { mothers }\end{array}$} & \multirow{3}{*}{$\begin{array}{l}\text { Total number of } \\
\text { previous pregnancies* }\end{array}$} & \multicolumn{4}{|c|}{ Previous spontaneous abortions } & \multirow[b]{3}{*}{$\chi^{2}$} & \multirow[b]{3}{*}{ Significance } \\
\hline & & & \multicolumn{2}{|c|}{ Cases } & \multicolumn{2}{|c|}{ Controlst } & & \\
\hline & & & $n$ & $\%$ & $n$ & $\%$ & & \\
\hline Neural tube defects & 72 & 101 & 25 & $24 \cdot 8$ & 13 & $12 \cdot 9$ & $5 \cdot 10$ & $p<0.05$ \\
\hline Holoprosencephaly & 88 & 140 & 32 & 22.9 & 19 & $13 \cdot 6$ & $4 \cdot 64$ & $\mathrm{p}<0.05$ \\
\hline Cleft lip & 84 & 133 & 45 & 33.8 & 19 & $14 \cdot 3$ & 16.49 & $p<0.01$ \\
\hline Polydactyly & 84 & 127 & 22 & $17 \cdot 3$ & 17 & 13.4 & 0.48 & NS \\
\hline Empty chorionic sac & 424 & 741 & 192 & $25 \cdot 9$ & 90 & $12 \cdot 1$ & 44.67 & $p<0.01$ \\
\hline Total & 706 & 1151 & 299 & $26 \cdot 0$ & 154 & 13.4 & 56.99 & $\mathrm{p}<0.01$ \\
\hline
\end{tabular}

* Excluding induced abortions.

$\dagger$ Normal controls matched for gravidity (excluding induced abortions), maternal age, and embryonic age at termination of pregnancy.

¥ Cases having two or more anomalies under study were counted only once.

NS $=$ Not significant.

from controls was statistically significant for all the anomalies except for polydactyly.

Table 4 shows the numbers of previous recognised pregnancies in the case mothers and normal controls, corrected for maternal age. The average number of prior pregnancies was smaller than that of normal controls for all the anomalies studied, and the difference was statistically significant for neural tube defects $(p<0.05)$. Twenty-six per cent $(19 / 72)$ of the mothers of embryos with neural tube defects were primigravidas, as opposed to only $11 \cdot 1 \%(8 / 72)$ of the control mothers $\left(\chi^{2}=4.56, \mathrm{p}<0.05\right)$. The proportion of primigravid mothers was $20.5 \%(18 / 88)$ for holoprosencephaly, which was more than twice as high as that of controls $(9 \cdot 1 \% ; 8 / 88)$ although the difference did not reach statistical significance $\left(\chi^{2}=3 \cdot 66,0.05<\mathrm{p}<0 \cdot 1\right)$.

The proportion of primigravid mothers and the frequency of prior spontaneous abortions were compared between cases with and without associated anomalies (table 5). For each anomaly, the proportion of primigravid mothers was larger in the cases with associated anomalies than in those without, although the differences were not statistically significant. Prior abortions were more frequent in the cases with multiple malformations, and significantly in cases with neural tube defects $\left(\chi^{2}=6 \cdot 10, p<0.02\right)$.

\section{Discussion}

The present study has shown that the mothers of defective embryos have greater than expected rates of 
Table 4 Previous recognised pregnancies in mothers of defective and normal embryos

\begin{tabular}{|c|c|c|c|c|c|c|c|c|c|c|c|}
\hline \multirow[b]{2}{*}{ Anomaly in index case } & \multirow[b]{2}{*}{ Group } & \multirow{2}{*}{$\begin{array}{l}\text { Number of } \\
\text { mothers }\end{array}$} & \multicolumn{8}{|c|}{ Number of previous recognised pregnancies } & \multirow[b]{2}{*}{ Significance } \\
\hline & & & 0 & $l$ & 2 & 3 & 4 & $5+$ & Mean & Variance & \\
\hline Neural tube defects & $\begin{array}{l}\text { Cases } \\
\text { Controls* }\end{array}$ & $\begin{array}{l}72 \\
72\end{array}$ & $\begin{array}{r}19 \\
8\end{array}$ & $\begin{array}{l}23 \\
12\end{array}$ & $\begin{array}{r}8 \\
18\end{array}$ & $\begin{array}{r}7 \\
14\end{array}$ & $\begin{array}{r}3 \\
11\end{array}$ & $\begin{array}{r}12 \\
9\end{array}$ & $\begin{array}{l}1 \cdot 94 \\
2 \cdot 58\end{array}$ & $\begin{array}{l}4.02 \\
3.01\end{array}$ & $\mathrm{p}<0.05$ \\
\hline Holoprosencephaly & $\begin{array}{l}\text { Cases } \\
\text { Controls* }\end{array}$ & $\begin{array}{l}88 \\
88\end{array}$ & $\begin{array}{r}18 \\
8\end{array}$ & $\begin{array}{l}21 \\
22\end{array}$ & $\begin{array}{r}9 \\
17\end{array}$ & $\begin{array}{r}8 \\
16\end{array}$ & $\begin{array}{r}10 \\
9\end{array}$ & $\begin{array}{l}22 \\
16\end{array}$ & $\begin{array}{l}2 \cdot 67 \\
2 \cdot 84\end{array}$ & $\begin{array}{l}5 \cdot 56 \\
5 \cdot 40\end{array}$ & NS \\
\hline Cleft lip & $\begin{array}{l}\text { Cases } \\
\text { Controls* }\end{array}$ & $\begin{array}{l}84 \\
84\end{array}$ & $\begin{array}{l}17 \\
20\end{array}$ & $\begin{array}{l}16 \\
14\end{array}$ & $\begin{array}{l}16 \\
12\end{array}$ & $\begin{array}{l}10 \\
13\end{array}$ & $\begin{array}{l}12 \\
10\end{array}$ & $\begin{array}{l}13 \\
15\end{array}$ & $\begin{array}{l}2 \cdot 44 \\
2 \cdot 49\end{array}$ & $\begin{array}{l}4 \cdot 39 \\
4 \cdot 71\end{array}$ & NS \\
\hline Polydactyly & $\begin{array}{l}\text { Cases } \\
\text { Controls* }\end{array}$ & $\begin{array}{l}84 \\
84\end{array}$ & $\begin{array}{l}14 \\
13\end{array}$ & $\begin{array}{l}21 \\
16\end{array}$ & $\begin{array}{l}20 \\
12\end{array}$ & $\begin{array}{l}10 \\
14\end{array}$ & $\begin{array}{r}6 \\
10\end{array}$ & $\begin{array}{l}13 \\
19\end{array}$ & $\begin{array}{l}2 \cdot 31 \\
2 \cdot 83\end{array}$ & $\begin{array}{l}4 \cdot 07 \\
4 \cdot 89\end{array}$ & NS \\
\hline Empty chorionic sac & $\begin{array}{l}\text { Cases } \\
\text { Controls* }\end{array}$ & $\begin{array}{l}424 \\
424\end{array}$ & $\begin{array}{l}69 \\
66\end{array}$ & $\begin{array}{l}85 \\
61\end{array}$ & $\begin{array}{l}66 \\
81\end{array}$ & $\begin{array}{l}58 \\
69\end{array}$ & $\begin{array}{l}47 \\
51\end{array}$ & $\begin{array}{l}99 \\
96\end{array}$ & $\begin{array}{l}2 \cdot 89 \\
2 \cdot 95\end{array}$ & $\begin{array}{l}6 \cdot 30 \\
5 \cdot 97\end{array}$ & NS \\
\hline Totalt & $\begin{array}{l}\text { Cases } \\
\text { Controls* }\end{array}$ & $\begin{array}{l}706 \\
706\end{array}$ & $\begin{array}{l}124 \\
106\end{array}$ & $\begin{array}{l}158 \\
120\end{array}$ & $\begin{array}{l}109 \\
134\end{array}$ & $\begin{array}{r}92 \\
118\end{array}$ & $\begin{array}{l}70 \\
83\end{array}$ & $\begin{array}{l}153 \\
145\end{array}$ & $\begin{array}{l}2 \cdot 69 \\
2 \cdot 82\end{array}$ & $\begin{array}{l}5 \cdot 53 \\
5 \cdot 36\end{array}$ & NS \\
\hline
\end{tabular}

* Normal controls matched for maternal age and embryonic age at termination of pregnancy.

$t$ Cases having two or more anomalies under study were counted only once.

NS $=$ Not significant

Table 5 Proportion of primigravidas and prior reproductive loss in mothers of defective embryos with and without associated malformations

\begin{tabular}{|c|c|c|c|c|}
\hline Type of anomaly & Number of cases & $\begin{array}{l}\text { Average maternal } \\
\text { age (years) }\end{array}$ & $\begin{array}{l}\text { Number of primigravidas } \\
(\%)\end{array}$ & $\begin{array}{l}\text { Abortions/previous pregnancies } \\
(\%)\end{array}$ \\
\hline \multicolumn{5}{|c|}{ Neural tube defects } \\
\hline $\begin{array}{l}\text { Isolated } \\
\text { Multiple }\end{array}$ & $\begin{array}{l}54 \\
18\end{array}$ & $\begin{array}{l}29 \cdot 5 \\
28 \cdot 4\end{array}$ & $\begin{array}{rr}13 & (24 \cdot 1) \\
6 & (33 \cdot 3)\end{array}$ & $\begin{array}{ll}14 / 77 & (18 \cdot 2) \\
11 / 24 & (45 \cdot 8) \dagger\end{array}$ \\
\hline \multicolumn{5}{|l|}{ Holoprosencephaly } \\
\hline Isolated & 59 & $30 \cdot 2$ & $10 \quad(16.9)$ & $24 / 109(22 \cdot 0)$ \\
\hline Multiple & 29 & $30 \cdot 3$ & $8 \quad(27 \cdot 6)$ & $8 / 31 \quad(25 \cdot 8)$ \\
\hline \multicolumn{5}{|l|}{ Cleft lip } \\
\hline Isolated & 58 & $30 \cdot 7$ & $9 \quad(15.6)$ & $33 / 99 \quad(33 \cdot 3)$ \\
\hline Multiple & 26 & $28 \cdot 2$ & $8 \quad(30 \cdot 8)$ & $12 / 34 \quad(35 \cdot 3)$ \\
\hline \multicolumn{5}{|l|}{ Polydactyly } \\
\hline Isolated & 60 & $28 \cdot 6$ & $9(15.0)$ & $16 / 97 \quad(16 \cdot 5)$ \\
\hline Multiple & 24 & $30 \cdot 4$ & $5 \quad(20.8)$ & $6 / 30 \quad(20 \cdot 0)$ \\
\hline \multicolumn{5}{|l|}{ Total } \\
\hline Isolated & 231 & $29 \cdot 4$ & $41 \quad(17 \cdot 7)$ & $87 / 382(22 \cdot 8)$ \\
\hline Multiple* & 51 & $29 \cdot 1$ & $13 \quad(25 \cdot 5)$ & $15 / 48 \quad(31 \cdot 3)$ \\
\hline
\end{tabular}

* Cases with two or more anomalies under study were counted only once.

t Significantly different from the cases without associated malformations $(p<0.02)$.

spontaneous abortion in previous pregnancies and fewer than expected previous pregnancies. Since maternal age was matched between the case and control groups in the analysis of previous pregnancies, the chance of fertilisation could not differ significantly between the two groups. This means that the number of prior pregnancies might be underestimated in the mothers of abnormal embryos, possibly due to increased subclinical loss of conceptuses in these women. Thus, both recognised and unrecognised reproductive losses appear to be more common in the women who conceived a defective embryo. Since a large proportion of spontaneously aborted embryos are abnormal, ${ }^{2-4}$ it seems that some mothers of malformed embryos may have conceived abnormal conceptuses repeatedly and experienced recurrent 
abortions which had not always been recognised clinically. It has been pointed out that spontaneous abortion is an important screening process that reduces the birth of malformed infants. ${ }^{10}$ In the present series, however, none of the women reported that she had had a malformed abortus before. This is probably because aborted embryos and fetuses are often seriously macerated and anomalies in early abortuses can be easily overlooked. Furthermore, some embryonic deaths may occur before organogenesis begins. ${ }^{11}$

Previous studies have shown the increased risk of spontaneous abortion in the mothers of infants with neural tube defects. The proportion of mothers of infants with these defects who reported any prior abortions was shown to be higher than that of control mothers. ${ }^{12-14}$ Record and McKeown ${ }^{15}$ found that the mothers of infants with central nervous system defects had an abortion rate of $11.2 \%$, compared with $7.5 \%$ in a control group. In South Wales, $17 \%$ of pregnancies prior to the birth of a child with a neural tube defect ended in abortion, significantly higher than $11.6 \%$ in the control population. ${ }^{16}$ Such studies in postnatal populations are usually based on retrospective interviews and they are sometimes criticised because of the possible overreporting by the mothers of defective infants. In the present study, such a reporting bias and maternal memory bias can be neglected, since neither the mothers nor the attending physicians were aware of the anomaly in the embryo, and since the interval between conception and termination of pregnancy was relatively short (up to 8 weeks) when the memory of the mother should be fresh and accurate.

It is interesting to note the previous finding that the rate of reproductive loss was lower in the families of cleft lip patients than the corresponding figure in the general population or in the families without cleft lip patients. ${ }^{17-19}$ In the data from Indiana and Montreal, none of the reported incidences of fetal mortality in sibships of cleft lip patients exceeded $11 \%$, which is lower than the accepted spontaneous abortion rate in the human. ${ }^{20} 21$ These data seem incompatible with our present result that the mothers of cleft lip embryos have an increased risk of spontaneous abortion. One possible explanation for such inconsistency is that the apparently reduced rate of reproductive loss in postnatal studies may be due to the selection of those families in which cleft lip embryos escaped spontaneous abortion and survived to birth. Secondly, compensatory reproduction may have occurred in the couples who gave birth to a malformed baby. Furthermore, maternal recall bias may have affected the reported incidence of spontaneous abortion, since in some postnatal cases family histories may have been taken several years after the birth of probands. Further epidemiological studies will be required to unravel the complex relation between the occurrence of oral clefts and reproductive loss in the families. No previous data regarding maternal reproductive loss are available for holoprosencephaly, polydactyly or empty chorionic sacs.

Our present data have shown that prior spontaneous abortions were more common in the mothers of embryos with multiple anomalies than in those of embryos with an isolated anomaly. According to Dronamraju and Bixler, ${ }^{20}$ the incidence of fetal mortality was found to be significantly greater in sibships of probands with bilateral cleft lip than in those of probands with unilateral cleft lip. These data suggest that the severity of malformations is positively associated with fetal mortality in the mother or other family members. Thus, they seem to support a multifactorial two threshold concept with a lower threshold beyond which the malformation occurs and a higher one beyond which the embryo dies. ${ }^{22}$

As for the effects of pregnancy order, the increased risk in births of children with neural tube defects to primiparous women has been reported by several investigators. ${ }^{23-25}$ Czeizel and Révész, ${ }^{23}$ in their large Hungarian study, showed the highest rate of neural tube defects in primiparas and especially in older primiparas. The risk of bearing a child with neural tube defect has been shown to be highest in first borns and decreases with birth order. ${ }^{26}$ These findings are consistent with our own finding that the mothers of abnormal embryos, especially those with neural tube defects, were more often primigravidas than the mothers of normal controls.

Our study suggests that the number of prior conceptions may be underestimated in the mothers of defective embryos, and this is probably also the case in postnatal studies. The elevated risk of births of infants with neural tube defects to primiparous women may suggest that some cases are conceived after unrecognised abortions. According to the data from Birmingham, England, an increased risk to firstborn was noted for anencephaly, spina bifida, hydrocephalus, and congenital dislocation of the hip. ${ }^{27}$ In this study, there was no evidence of an association between birth rank and the occurrence of oral clefts. No data have been reported concerning the effects of birth order on the occurrence holoprosencephaly, polydactyly and empty chorionic sacs.

The significance of our finding is twofold. First, abortion prone women and women with subnormal fertility have an increased risk of having a malformed embryo. Second, some mothers appear to conceive defective conceptuses repeatedly but many of these escape clinical detection. Such "silent" recurrent cases may be related to some predisposition of the mother which can be genetic, environmental, or both. 
Environmental factors may include social, nutritional and other maternal factors. Lower socioeconomic status and undernutrition have been implicated in the occurrence of neural tube defects. ${ }^{28-33}$ In Japan, however, socioeconomic status appears quite uniform and nutrition problems are rare these days. Some other factors which are genetic or biological in origin may possibly be related to the predisposition of the mothers. The effects of maternal age per se or those of the chromosome abnormalities for which the risk increases with advancing maternal age can be excluded because the average maternal age was not significantly different between the case and control groups. Balanced translocations are the most well documented chromosome abnormalities in couples with multiple miscarriages. These anomalies have been found in $2-8 \%$ of the couples experiencing multiple abortions. ${ }^{34-37}$ The cases in the present study were not examined cytogenetically, and the role of chromosome aberrations in the causation of recurrent embryonic abnormalities should be studied in future. It is noteworthy that in the present study, the mothers of embryos with syndromic neural tube defects had significantly more previous miscarriages than the mothers of those with isolated neural tube defects. Malformation complexes or syndromes are often associated with chromosome abnormalities, but the implication of our finding awaits further investigation.

Clarke et $a{ }^{38},{ }^{38}$ suggested that neural tube defects may arise from an interaction between an embryo and a trophoblastic cell rest remaining from a previous pregnancy. They postulated that such a cell rest is more likely to occur after a spontaneous abortion than after a normal delivery. Our data showing that both recognised and unrecognised abortions are relatively common in the mothers of embryos with neural tube defects do not contradict this hypothesis.

It is well known that many malformations occur sporadically without an apparent family history. This occurrence, however, must be underestimated because a substantially large number of abnormal embryos are screened out prenatally and often escape clinical detection. In genetic counselling, information on the fertility and prior reproductive loss of the mother should be examined carefully to provide a basis for prognosis of her pregnancy and a criterion for selecting patients for antenatal diagnosis.

The contribution of our colleagues in the Department of Anatomy and Congenital Anomaly Research Centre of Kyoto University is gratefully acknowledged. We also thank the collaborating obstetricians for their continued help. This work was supported in part by a grant from the Ministry of Health and Welfare, Japan.

\section{References}

${ }^{1}$ Nishimura H. Prenatal versus postnatal malformations based on the Japanese experience on induced abortions in the human being. In: Blandau RJ, ed. Aging gametestheir biology and pathology. Basel: Karger, 1975: 349-68.

2 Boué J, Philippe E, Giroud A, Boué A. Phenotypic expression of lethal chromosomal anomalies in human abortuses. Teratology 1976; 14: 3-20.

${ }^{3}$ Poland BJ, Miller JR, Harris M, Livingstone J. Spontaneous abortion. A study of 1961 women and their conceptuses. Acta Obstet Gynecol Scand (Suppl) 1981; 102: $1-32$.

${ }^{4}$ Hook EB. Prevalence of chromosome abnormalities during human gestation and implications for studies of environmental mutagens. Lancet 1981; ii: 169-72.

${ }^{5}$ Creasy MR, Alberman ED. Congenital malformations of the central nervous system in spontaneous abortions. $J$ Med Genet 1976; 13: 9-16.

${ }^{6}$ Miller JF, Williamson E, Glue J, Gordon YB, Grudzinskas JG, Sykes A. Fetal loss after implantation. A prospective study. Lancet 1980; ii: 554-6.

${ }^{7}$ Whittaker PG, Taylor A, Lind T. Unsuspected pregnancy loss in healthy women. Lancet 1983; i: 1126-7.

${ }^{8}$ Matsunaga E, Shiota $\mathrm{K}$. Holoprosencephaly in human embryos: Epidemiology of 150 cases. Teratology 1977; 16: 261-72.

${ }^{9}$ Shiota K, Nishimura H. Epidemiology of induced abortion in Japan. In: Hafez ESE, Ed. Voluntary termination of pregnancy. Lancaster: MTP Press, 1984: 3-10.

10 Warkany J. Terathanasia. Teratology 1978; 17: 187-92.

${ }^{11}$ Shiota K, Uwabe C, Nishimura H. High prevalence of defective human embryos at the early postimplantation period. Teratology 1987; 35: 309-16.

12 Coffey VP, Jessop WJE. A study of 137 cases of anencephaly. Br J Prev Soc Med 1957; 11: 174-80.

${ }^{13}$ Fedrick J. Anencephalus in the Oxford Record Linkage study area. Dev Med Child Neurol 1976; 18: 643-656.

${ }^{14}$ Granroth G, Haapakoski J, Hakama M. Defects of the central nervous system in Finland. II. Birth order, outcome of previous pregnancies and family history. Teratology 1978; 17: 213-22.

15 Record RG, McKeown T. Congenital malformations of the central nervous system. III. Risk of malformation in sibs of malformed individuals. Br J Prev Soc Med 1950; 4: 217-20.

${ }^{16}$ Richards IDG. Fetal and infant mortality associated with congenital malformations. Br J Prev Soc Med 1973; 27: 85-90.

17 Warburton D, Fraser FC. Spontaneous abortion risks in man: Data from reproductive histories collected in a medical genetics unit. Am J Hum Genet 1964; 16: 1-25.

18 Henriksson T-G. Cleft lip and palate in Sweden. Uppsala: Uppsala Institute for Medical Genetics of the University of Uppsala, 1971.

${ }^{19}$ Bear JC. The association of fetal wastage with facial cleft conditions. Cleft Palate $J$ 1973; 10: 346-59.

${ }^{20}$ Dronamraju KR, Bixler D. Fetal mortality and cleft lip with or without cleft palate. Clin Genet 1983; 23: 38-40.

${ }^{21}$ Dronamraju KR, Bixler D. Fetal mortality in oral cleft families: Data from Indiana and Montreal. Clin Genet 1983; 23: 350-3.

22 Niswander JD, MacLean CJ, Chung CS, Dronamraju K. Sex ratio and cleft lip with or without cleft palate. Lancet 1972; ii: 858-60.

${ }^{23}$ Czeizel A, Révész C. Major malformations of the nervous system in Hungary. Br J Prev Soc. Med 1970; 24: 205-22.

24 Horowitz I, McDonald AD. Anencephaly and spina bifida in Quebec. Can Med Assoc J 1969; 100: 748-55. 
${ }^{25}$ Elwood JM, McBride ML. Contrasting effects of maternal fertility and birth rank on the occurrence of neural tube defects. J Epidemiol Community Health 1979; 33: 78-83.

26 James WH. Central nervous system malformation stillbirths, maternal age and birth order. Ann Hum Genet 1969; 32: 223-36.

${ }^{27}$ McKeown T. Sources of variation in the incidence of malformations. In: First International Conference on Congenital Malformations. Philadelphia and Montreal: Lippincott, 1961: 45-52.

${ }^{28}$ Williamson EM. Incidence and family aggregation of major congenital malformations of the central nervous system. J Med Genet 1965; 2: 161-72.

${ }^{29}$ Richards IDG, Roberts CJ, Lloyd S. Area differences in prevalence of neural tube malformations in South Wales. Br J Prev Soc Med 1972; 26: 89-93.

${ }^{30}$ Carter CO, Evans K. Spina bifida and anencephalus in Greater London. J Med Genet 1973; 10: 209-34.

${ }^{31}$ Elwood JH, Nevin NC. Factors associated with anencephalus and spina bifida in Belfast. Br J Prev Soc Med 1973; 27: 73-80.

32 Emanuel I, Sever LE. Questions concerning the possible association of potatoes and neural-tube defects, and an alternative hypothesis relating to maternal growth and development. Teratology 1973; 8: 325-32.
33 Baird D. Epidemiology of congenital malformations of the central nervous system in (a) Aberdeen and (b) Scotland. J Biosoc Sci 1974; 6: 113-37.

${ }^{34}$ Sant-Cassia LJ, Cooke P. Chromosomal analysis of couples with spontaneous abortions. Hum Genet 1981; 88: 52-8.

${ }^{35}$ Schwartz S, Palmer CG. Chromosomal findings in 164 couples with repeated spontaneous abortions: With special consideration to prior reproductive history. Hum Genet 1983: 63: 28-34.

${ }^{36}$ Campana M, Serra A, Neri G. Role of chromosome aberrations in recurrent abortion: A study of 269 balanced translocations. Am J Med Genet 1986; 24: 341-56.

${ }^{37}$ Castle D, Bernstein R. Cytogenetic analysis of 688 couples experiencing multiple spontaneous abortions. Am J Med Genet 1988; 29: 549-56.

${ }^{38}$ Clarke CA, Hobson D, McKendrick OM, Rogers SC, Sheppard PM. Spina bifida and anencephaly: Miscarriage as possible cause. $\mathrm{Br} \mathrm{Med} J$ 1975; iv: 743-6.

Accepted for publication January 1989 